\title{
Combating political crimes committed by members of informal youth groups
}

\section{Боротьба з політичними злочинами, що вчиняються членами молодіжних неформальних груп}

Received: May 2, 2021

\section{Abstract}

In modern conditions of the development of public relations and political life, criminal activity in Ukraine is changing and transforming. In such transformational conditions, the commission of political crimes by members of informal youth groups is becoming more widespread. Given the above, the need to analyze political crimes committed by members of informal youth groups, methods, and means of combating such crimes, including foreign positive experience, becomes especially relevant. The work aims to analyze the means and methods of combating political crimes committed by members of such groups. The object of the research is the fight against political crimes committed by members of informal youth groups. The subject of the study is the social relations that arise, change, and end during the fight against political crimes committed by members of these groups. The research methodology is a set of different scientific methods, including observation, analysis, synthesis, extrapolation, generalization, comparison, dialectical method. The empirical
Accepted: June 5, 2021

Written by:

Mikhail Larkin ${ }^{29}$

https://orcid.org/0000-0002-4676-460X

Viktor Boiarov ${ }^{30}$

https://orcid.org/0000-0001-9155-505X

Volodymyr Buha ${ }^{31}$

https://orcid.org/0000-0002-0655-5256

Ivan Kubariev ${ }^{32}$

https://orcid.org/0000-0003-1053-9758

Yuliia Loboda ${ }^{33}$

https://orcid.org/0000-0002-1772-3227

\section{Анотація}

У сучасних умовах розвитку суспільних відносин та політичного життя змінюється та трансформується злочинна діяльність в Україні. В таких трансформаційних умовах все більшого поширення набуває вчинення політичних злочинів членами молодіжних неформальних груп. Зважаючи на вищевикладене, особливої актуальності набуває необхідність аналізу політичних злочинів, що вчиняються членами молодіжних неформальних груп, способів і засобів боротьби $з$ такими злочинами, в тому числі іноземного позитивного досвіду. Метою роботи є здійснення аналізу засобів та способів боротьби 3 політичними злочинами, що вчиняються членами молодіжних неформальних груп. Об'єктом дослідження є боротьба з політичними злочинами, що вчиняються членами молодіжних неформальних груп. Предметом дослідження $є$ суспільні відносини, що виникають, змінюються і припиняються під час боротьби 3 політичними злочинами, що вчиняються членами молодіжних неформальних груп.

\footnotetext{
${ }^{29} \mathrm{Ph}$. D., Associate Professor, Associate Professor of Department of Criminal Law and Justice of Zaporizhzhia National University, Ukraine.

${ }^{30} \mathrm{Ph}$. D., Associate Professor, Professor of Department of Criminal Procedure and Forensics of Academy of Advocacy of Ukraine, Ukraine.

${ }^{31}$ Ph. D., Associate Professor, Dean of the Faculty No. 3 of Donetsk Law Institute of the Ministry of Internal Affairs of Ukraine, Ukraine.

${ }^{32}$ Ph. D., Associate Professor, Head of the Department of Criminal Legal disciplines of the Faculty No. 2 of Donetsk Law Institute of the Ministry of Internal Affairs of Ukraine» Ukraine.

${ }^{33} \mathrm{Ph}$. D., Associate Professor, Associate Professor of the Department of Theory and Practice of English Translation of Taras Shevchenko National University of Kyiv, Ukraine.
} 


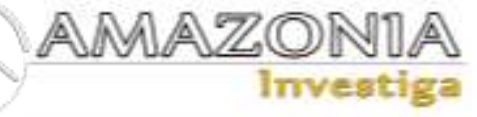

basis of the study was the materials of the investigation of crimes committed by members of informal youth groups. As a result of the study, some issues of combating political crimes committed by members of informal youth groups were considered. Three main reasons for the participation of informal youth groups in political confrontations are highlighted, and certain issues of investigation of this type of criminal activity are considered.

Keywords: political crimes, political confrontations, political party, investigation, youth, informal group.
Методологію дослідження складає комплекс різних наукових методів, серед яких: спостереження, аналіз, синтез, екстраполяція, узагальнення, порівняння, та діалектичний метод. Емпіричною основою дослідження стали матеріали розслідування злочинів, скоєних членами молодіжних неформальних груп. В результаті проведеного дослідження були розглянуті деякі питання боротьби 3 політичними злочинами, що здійснюються членами молодіжних неформальних груп. Виділено три основні причини участі молодіжних неформальних груп в політичних протистояннях, а також розглянуті окремі питання розслідування зазначеного виду злочинної діяльності.

Ключові слова: політичні злочини, політичні протистояння, політична партія, розслідування, молодь, неформальна група.

suffrage, discriminatory behavior of state bodies against members of opposition movements and parties, errors, and miscalculations in national policy, including the imposition of the ruling elite's ideology and socio-political practices unacceptable to society. Thus, the cause of political crime is the lack of stability in society. A dilemma arises when stability becomes the highest social value of society but is achieved with a high level of authoritarianism with accompanying political and legal flaws of power. At present, Ukraine needs a complex and long way to balance the interests of power and segments of society, provided the appropriate level of political and legal culture, which also leads to political stability.

The protest movement in Ukraine is based on the unwillingness of the authorities and informal organizations to understand each other, open disregard for rights and responsibilities, failure to ensure constructive dialogue to maintain public peace in society - these and other factors have led to a sharp rise in political crime and Ukraine has become an arena for criminal political battles.

According to statistical reports of the Prosecutor General's Office, in 2019 all law enforcement agencies (except the National Anti-Corruption Bureau of Ukraine) allegedly exposed 293 organized criminal groups, which is really slightly more than in 2013-2018 (in 2018 - 288, in 2017 - 210, in 2016 - 136 and 185 - in 2013), but, at the same time, much less than in 2010 397 and in 2009 - 379, as well as 16 criminal organizations, which is also more indicators of 
2016-2018. At the same time, the fact that out of the total number of organized criminal groups and criminal organizations detected in 2019, 29 were with corrupt connections, which is also more than in 2018 - 21, in 2017 - 25, in 2016 - 15 and $2015-17$, but, again, less than in $2014-32$ and, even more so, in 2013 - 33 (Slovo i Dilo, 2018). Simultaneously, in 2019, the number of identified organized criminal groups and criminal organizations with international relations decreased - 6 - in 2018 - 7, in 2017 - 11, in 2016 - 18, and compared to 2010, when 40 of them were detected, less than 6 times (Shekhavtsov, \& Khavronyuk, 2019). In addition, according to statistics, in 2019, a total of 2,437 criminal offenses were allegedly committed as part of the organized criminal group and the Criminal Organization, which is less than in $2018-2,513$, in $2010-3,135$ and $2009-3,514$, but more than in the previous two years: in 2017 - 1,727, and 2016 - 1,235 (Baganets, 2020).

Given the above, there is an urgent need to research the fight against political crimes committed by members of informal youth groups, the causes of such crimes, the possibility of their prevention, as well as to analyze the specifics of combating such crimes in foreign countries.

\section{Theoretical Framework or Literature Review}

When working on the article, the scientific literature was analyzed, devoted to the fight against crime, its causes; investigation of political crimes; investigation of group crimes; informal youth groups (associations, movements, etc.).

The combat against political crimes committed by members of informal youth groups has been studied by the following scientists: Kabanov (2008), Meneghetti (2005), Zelensky, Meretukov, Gusev, and Danilyan (2013), Ananich and Anikeeva (2017), Fromm (2013), Kolomoiets, Liutikov, and Larkin (2017), Lisovets (2011), Roszak (1995), Shepitko (2009), Larkin, Dudorov, Pyrozhkova, Dudorova, and Biryukova (2020), and Gross (2002). However, crimes committed by members of informal youth groups and ways to combat them, unfortunately, are insufficiently studied.

Thus, Kabanov (2008) considered political crime: concept, essence, types, reasons, the personality of a political criminal, countermeasures. The researcher believes that the difficulty of crime traditionally occupies one of the leading positions in public opinion among the most acute social problems. There has been a sharp increase in the number of crimes committed, and their social danger has increased. Criminological studies of "political repression" and scientific analysis of political events associated with the collapse of interstate associations (Warsaw Pact, USSR), accompanied by interethnic, ethnic, and political conflicts, led experts to the conclusion that crime associated with obtaining and retaining power reality. In this regard, the first major scientific publications by criminologists about crime among the ruling political elite appeared, while the most dangerous forms of its manifestation were indicated: political terrorism (violence by the authorities) and political corruption (the corruption of power).

Moreover, Kudryavtsev and Eminov (2005) studied the general provisions on crime and the composition of the crime, which allowed him to avoid logical errors in the study of a crime.

What is more, Aphorisms by Schopenhauer (2012), the works of Meneghetti (2005) and Fromm (2013) were used to understand the life wisdom of prominent people on political crime and the psychological foundations of the analysis of criminal behavior.

Further, Ananich and Anikeeva (2017) drew attention to the analysis and forecasting of crime and noticed that, based on the study of the mechanisms used by international organizations and other countries in the fight against crime, the degree of their use in the Republic of Belarus is analyzed and special attention is paid to the experience in assessing corruption risks, approaches to their identification. Based on statistical data on corruption crime, a general analysis of the influence of individual factors on its dynamics is carried out.

Additionally, Kolomoiets, Liutikov, and Larkin (2017) analyze the informal youth associations as a business reality. So, an informal youth environment is not only an integral part of today's reality but also a complex multi-vector problem. In the study, the informal associations are divided into three groups: informal youth associations, on which people earn (skinheads and hipsters); informal youth associations that earn (freaks, suicidal groups in social networks); informal youth associations, on which people earn and that earn (anime fans, gamers, bikers, football fans). The researchers concluded that the "life activity" of informal communities is predetermined not only by some ideas, views, 
moods, way of life but also by business opportunities and opportunities to make a profit. Thus, for the first time since Ukraine gained independence, informal youth groups are seen as a platform for engaging in entrepreneurial activities. The results of the study can be used to further study various aspects of the informal youth environment. In particular, in the context of combating illegal business activities, tax evasion.

Also, Larkin (2019) analyzed the causes of informal youth groups (associations) of criminal orientation. He noted that the analysis, in the context of forensic research, the problems of informal youth groups (associations) of criminal orientation, as a complex socio-legal phenomenon, suggests three principal causes such formations:

1) crisis processes in family relations;

2) age characteristics of the adolescent, and;

3) global policy of conformism.

These reasons are subject to clarification, additional study and should be the subject of comprehensive research.

It should be mention, Lisovets (2011) examined in detail and developed a book, which considered the theory and methods of working with children's and youth organizations in Ukraine.

It also worth to note, that Zelensky, Meretukov, Gusev, and Danilyan (2013) and Shrub (2018) explained the forensic methods of investigating certain types and groups of crimes and drew attention to the fact that the forensic mechanism of committing a crime, being individual for each act, also has common, repeating properties. For crimes of one type, typical may be: the method, the setting of the commission, connections, and other factual data generated in this case. Elements of an investigation may also be typical: evidence, its sources, means, and methods of obtaining it. The investigation methodology is based on criminal and criminal procedure legislation. Criminal law defines the concept of a crime, its composition, and other fundamental issues, the specific type of crimes. Criminal procedural norms provide for the circumstances to be proved and the means of collecting evidence. The content of the methodology includes the theoretical provisions of forensic science and the generalized experience of investigating crimes.

A particular attention should be paid to the work of Shepitko (2009), who developed a course of lectures "criminology", which were taken as a basis for this study, providing definitions of concepts and areas of combating political crime. Moreover, Larkin, Dudorov, Pyrozhkova, Dudorova, and Biryukova (2020) analyzed the issue of the investigation of crimes committed by members of informal youth groups. In their research, the authors concluded, the features of proposing a version of the involvement of members of a informal youth group in criminal activity are considered. Initial investigative (search) actions are determined, which serve as the basis for verifying the indicated version.

Furthermore, Boiarov, Larkin, Legkykh, Melkovskyi, and Hromova (2019) studied the problem of the prevention of the financing informal youth groups of the extremist. Their article proposes to divide all informal youth groups (associations) that commit crimes of extremist nature into two types:

1) formed by its leader(s), and;

2) acting as the youth part of international extremist organizations, radical movements, and political parties.

The works, devoted to the study of the psychology of investigative activity, transnational extremism, were also analyzed, and the guidelines for forensic investigators were retrospectively examined (Gross, 2002; Davydov, 2016; Kazmirenko, 2009).

It is worth paying attention to the book of Larkin (2020), who analyzed the peculiarities of the use of linguistic knowledge in the investigation of crimes committed by members of informal youth groups (associations). The author emphasizes that the development of different methods of generalization of criminalistic methods of investigation of criminally punishable manifestations of extremism, in particular those committed by members of informal youth groups, is becoming quite relevant for both law enforcement practitioners and forensic scientists. Moreover, it should be taken into account that this process is complicated by the lack of a legislative definition of extremism, extremist activity, extremist formation (organization), etc. in Ukraine. The quality of the planning of the initial stage of the investigation of crimes committed by members of informal youth groups (associations), in particular extremist ones, largely determines whether the perpetrators will be exposed. Also, some questions of planning of investigation in the specified category of criminal encroachments are defined, problematic questions of inspection of a scene are considered. 
The purpose of the inspection of the scene in these criminal proceedings is: to identify traces of the offense and physical evidence; clarifying the circumstances of the event that is the subject of the investigation; other circumstances that are relevant to the proceedings (data on persons eyewitnesses and participants, organizers of the event, the victims, as well as the presentation of versions of the event, that is the subject of the investigation). In addition, the specifics of the interrogation of individual participants in these criminal proceedings (victim, witness) have been established. It is highlighted that in the process of investigating extremist manifestations of informal youth, the investigator cannot neglect two forms of special knowledge, namely:

1) involvement of specialists in conducting investigative (search) actions, and;

2) appointment of forensic examinations.

Finally, Larkin, Biryukova, Makarenko, Ivanova, and Fedchyniak (2020) analyzed typical mistakes during investigation of crimes committed by informal youth groups members. The authors concluded that the problem of juvenile delinquency is becoming general every year, a typical phenomenon not only in Ukraine, but also in other countries in the world; consequently, there is an urgent need to develop new interdisciplinary methods to combat this phenomenon and to understand its multidimensional causes and consequences.

Further directions of research of ways to counteract crimes committed by representatives of informal youth groups may concern the influence of the state youth policy on the formation of protest moods and the emergence of intentions to commit political crimes.

\section{Methodology}

dialectical method. The empirical basis of the study was the materials of the investigation of crimes committed by members of informal youth groups.

Thus, the method of observation was used in the study of the materials of criminal proceedings, which became the basis for the formulation of some provisions of the article. This method also made it possible to remotely observe the change in the criminal behavior of informal groups during various political events in Ukraine and thus to record the dynamics of crime.

In addition, the method of analysis was used in the study of scientific sources; the practice of investigating political crimes and crimes committed by informal youth. In addition, the method of analysis allowed us to consider in detail the regulations of both international and Ukrainian in the fight against political crime and highlight their main provisions. This method helped to analyze the statistical data of law enforcement agencies on the fight against organized crime. The obtained data made it reasonable to conclude the circumstances that influenced the formation of political crime and to form ways to combat it. Also, the method of analysis in the study of legal documents, articles, and monographs was used to make a comparison. Thanks to this method, it was possible to make a comprehensive comparison of the current state of the fight against the crime studied in the article.

With the help of synthesis, separate recommendations for combating crimes committed by members of informal youth groups were generalized.

The extrapolation method was used for the study of scientific sources devoted to the investigation of crimes committed by members of informal youth groups.

Besides, the generalization method was used to formulate conclusions and write an article on the fight against crimes committed by members of informal youth groups. The method of generalization also helped to unite the general provisions on organized crime and its regulation in Ukraine, taking into account various international legal acts. That is, this method helped to summarize the individual conclusions and existing experience in this article to develop methods for an effective combating political crime.

The method of comparison allowed us to compare the fight against political crime and the investigation of crimes in Ukraine and the world. Thus, the current legislation, crime statistics in the country in general, administrative bodies, crime rate were compared. A detailed comparison allowed us to analyze the fight against crime in Ukraine and abroad to clarify the problematic issues and implement the positive foreign experience in Ukraine.

Finally, using a dialectical method, the legislation that establishes ways to combat such crime at different times and various conditions was investigated. Thus, in historical retrospect, it was analyzed how the political crime was established in Ukraine and the world and what factors influenced such formation. The results, in 


\section{AMAZONDA}

turn, helped to set that mental and historical preconditions affect the establishment of political crime and the level of crime in the country.

\section{Results and Discussion}

The reasons for the participation of informal youth groups in political confrontations

Political protests, political actions, and as a result - political confrontations, covering hundreds of countries around the world, have become a reality today. In this regard, the attraction of informal youth to protest moods that develop into political crimes has become an attributive component of modern politics.

The study of causality in the context of the investigation of political crimes of informal youth is the most important analytical and legal work, which is designed to show the true picture of political events. Meneghetti wrote: "Life is a cause that cannot take back its consequences, as long as it is brought into fulfillment (Meneghetti, 2005).

Causality (causality) is an objective connection between phenomena, one of which (cause) gives rise to another (effect) (Ananich, \& Anikeeva, 2017).

Analysis of scientific sources, materials of criminal proceedings for the investigation of political crimes committed by members of informal youth groups, makes it possible to assume the presence of three main reasons for their illegal (in this case, criminal) activity:

1) the goals, objectives, ideology of the informal group is aimed at opposing itself to the existing world order, state structure, political regime, that is, at the political struggle against the current order. Fromm wrote: "Modern society needs people who easily interact within large groups, want to consume more and more, have standard needs, and besides, they are suggestible and predictable people." (Fromm, 2013). And here it can be argued that the majority of such informal youth groups are extremist, but at the same time, they are totally "ideologically" directed. They do not see specific political goals (for example, participation in elections of a particular type), but are fighting the entire world order, which they personify with the state in which such an informal youth group is formed;

2) an informal youth group (s) is a "youth wing" of a political party that attracts informal youth for power political confrontations (rallies, actions) that develop into political crimes. Leaders (participants) of such youth formations can take part in elections, they are in the political council of the party. E.g., informal group operates within the framework established by the political party.

3) an informal youth group, hiding behind ideological convictions, is a business project and can take part in the political activities of both the current government and their political opponents.

So, informal associations can be divided into three groups:

$>$ informal youth associations, on which persons earn money;

$>$ informal youth associations that earn money;

$>$ informal youth associations, on which persons earn and which earn (Kolomoiets, Liutikov, \& Larkin, 2017).

In addition, special attention should be paid to the study of the reasons for the entry of young people into informal communities. So, there are three main reasons for the emergence of such formations:

1) crisis processes in family relationships;

2) age characteristics of a teenager;

3) global policy of conformism (Larkin, 2019).

Of course, these reasons are subject to clarification, additional study and should become the subject of comprehensive scientific research. It should also be noted that sometimes an informal youth group actively develops norms and values that contradict the generally accepted culture, its content, and forms, and a counterculture is formed on their basis (Lisovets, 2011).

Features of the investigation of political crimes committed by members of informal youth groups

The forensic mechanism for committing a crime, being individual for each act, also has common, repeating properties. For crimes of one type, the typical may be the way, the setting of the commission, the connections, and other factual data generated in this case. Elements of an investigation may also be typical: evidence, sources, means, and methods of obtaining them (Zelensky, Meretukov, Gusev, \& Danilyan, 2013). The task of the investigator is, based on 
knowledge of the typical, to apply forensic recommendations to a specific individual case of investigation (Shrub, 2018).

The primary task in the investigation of political crimes committed by members of informal youth groups is a thorough study of the trail pattern, in particular, the specific traces that may suggest the involvement of "informals". The mechanism of trace formation (the system of components of the process of formation of traces-mappings) is also subject to study (Shepitko, 2009).

Special attention should be paid to such urgent investigative (search) actions as inspection of the scene of the incident, interrogation of the suspect (in the event of his arrest) (Larkin, Dudorov, Pyrozhkova, Dudorova, \& Biryukova, 2020).

Careful consideration should be given to the study of testimony in the investigation of political crimes committed by members of informal youth groups. Even Hans Gross warned: "However, we must constantly keep in mind that every testimony can be false. This is not an excessive distrust, but only caution and knowledge of one's business, for false testimony is often clothed in the most innocent and suspicious forms." (Gross, 2002).

A significant investment of time is required to determine the sources of funding for informal youth formations in the investigation of crimes of a political nature. Thus, a study of the financing of informal youth groups of extremist orientation showed that a type of informal youth association determines the ways of receiving funding. In this regard, all informal youth groups (associations) that commit crimes of an extremist nature should be divided into two types:

1) independently formed by its leader (leaders) and;

2) those that act as a "youth wing" of international extremist organizations, radical movements, and political parties (Boiarov, Larkin, Legkykh, Melkovskyi, \& Hromova, 2019).

It should also be noted that from the standpoint of the science of forensic science, the investigation of criminal activity includes the process of creating an information model of a crime event (Davydov, 2016). When investigating political crimes committed by members of informal youth groups, three blocks of information are subject to study:

$>$ information regarding the event of the crime;
$>$ information on the specifics of the informal youth group;

$>$ information on methodological recommendations (information resources) for the investigation of this type of crime.

In the process of investigating this category of criminal proceedings, the investigator, getting into a specific information field, limited by the specifics of a particular crime and the focus of a specialist on it (Kazmirenko, 2009), cannot neglect two forms of special knowledge, namely:

1) the involvement of specialists in the conduct of investigative (search) actions;

2) the appointment of forensic examinations.

Of particular importance is the use of linguistic knowledge in the investigation of political crimes committed by members of informal youth groups (Larkin, 2020).

When analyzing recommendations for the investigation of crimes committed by members of informal youth groups, the investigator should pay attention to typical mistakes that can be made during the investigation (Larkin, Biryukova, Makarenko, Ivanova, \& Fedchyniak, 2020).

\section{Conclusions}

As a result of the study, some issues of combating political crimes committed by members of informal youth groups were considered.

There are three main reasons for the participation of informal youth groups in political confrontations, namely, informal youth associations, which earn money; informal youth associations that earn money; informal youth associations, which earn and which earn.

1. When investigating political crimes committed by members of youth informal groups, it is necessary to examine three blocks of information: information about the event of the crime; information on the specifics of the youth informal group; information on methodological recommendations (information resources) for the investigation of this type of crime.

2. When investigating the investigated crimes, the use of linguistic knowledge in the investigation of political crimes committed by members of informal youth groups and drawing attention to typical mistakes that can be made during the investigation is of particular importance. 


\section{AMAZONDA \\ Invertiga}

Also, some issues of investigation of the specified type of criminal activity are considered. A promising area of further scientific research is the development of guidelines for the investigation of illegal actions of informal youth and the formation of this crime separately.

\section{Bibliographic references}

Ananich, V.A., \& Anikeeva, N.A. (2017). Analysis and forecasting of crime. Minsk: Academy of the Ministry of Internal Affairs.

Baganets, O. (2020). The general state of crime and combating it in Ukraine in 2019 (compared to statistics for 2013-2018). Baganets. Recovered from http://baganets.com/blogs-baganets/zagalniistan-zlochinnost-ta-protid-i-na.html

Boiarov, V., Larkin, M., Legkykh, K., Melkovskyi, O., \& Hromova, M. (2019). Ways to Prevent the Financing Youth informal Groups of the Extremist. Amazonia Investiga, 8(24), 479-483. Recovered from

https://amazoniainvestiga.info/index.php/amazonia /article/view/1007

Davydov, V.O. (2016). Transnational extremism: forensic analysis. Moscow: Yurlitinform.

Fromm, E. (2013). You will be like gods. Moscow: AST. ISBN: 978-5-17-079747-9. Recovered from https://spblib.ru/catalog/-/books/11002170-vybudete-kak-bogi

Gross, G. (2002). Guidelines for forensic investigators as a system of criminalistics. Moscow: LexEst. Recovered from https://www.twirpx.com/file/1263098/

Kabanov, P.A. (2008). Political crime: concept, essence, types, reasons, personality of a political criminal, countermeasures (criminological research) (doctoral thesis). Institute of Management, Economics and Law, Ekaterinburg. Recovered from https://www.dissercat.com/content/politicheskayaprestupnost-ponyatie-sushchnost-vidy-prichinylichnost-politicheskogo-prestu-0

Kazmirenko, L.I. (2009). Psychology of investigative activity. Kyiv: Legal Unity.

Kolomoiets, T., Liutikov, P., \& Larkin, M. (2017). Informal youth associations as a business reality. Baltic Journal of Economic Studies, 3(5), 294-297. DOI Recovered from https://doi.org/10.30525/2256-0742/2017-3-5-294297.

Kudryavtsev, V.N., \& Eminov, V.E. (2005). Criminology. Moscow: Yurist. ISBN: 5-37000149-9 978, 5-7975-0647-5.

Larkin, M., Biryukova, A., Makarenko, T., Ivanova, N., \& Fedchyniak, A. (2020). Typical mistakes during investigation of crimes committed by youth informal groups members. Cuestiones Políticas, 38(66), 396-405.
Larkin, M., Dudorov, O., Pyrozhkova, Y., Dudorova, K., \& Biryukova, A. (2020). Investigation of crimes committed by members of youth informal groups. Amazonia Investiga, 9(29), 282-287. DOI Recovered from https://doi.org/10.34069/AI/2020.29.05.32.

Larkin, M.O. (2019). Causes of youth informal groups (associations) of criminal orientation. Scientific Bulletin of the International Humanities University, 2(41), 115-117. Recovered from https://scientific-

rating.znu.edu.ua/index.php?r=publication $\% 2$ Fvie w\&id $=8037$

Larkin, M.O. (2020). Features of the use of linguistic knowledge in the investigation of crimes committed by members of informal youth groups (associations). Zaporozhye: Helvetica Publishing House.

Lisovets, O.V. (2011). Theory and methods of working with children's and youth organizations of Ukraine. Kyiv: VC "Academy". Recovered from https://academia-pc.com.ua/product/249

Meneghetti, A. (2005). Project "Man". Moscow: NSBF "Ontopsychology". Recovered from https://www.twirpx.com/file/988236/

Roszak, T. (1995). The Making of a Counter Culture. Reflections on the Technocratic Society and Its Youthful Opposition, With a new introduction. New York: University of California. ISBN: 9780520201224 Recovered from https://monoskop.org/images/b/b4/Roszak_Theodo re_The_Making_of_a_Counter_Culture.pdf Schopenhauer, A. (2012). Aphorisms of worldly wisdom. St. Petersburg: Azbuka, Azbuka-Atticus. Recovered from https://royallib.com/book/shopengauer_artur/aforiz mi_giteyskoy_mudrosti_sbornik.html

Shekhavtsov, R., \& Khavronyuk, M. (2019). Criminal Statistics Report. Kyiv: Center for Political and Legal Reforms. Recovered from https://rpr.org.ua/wp-

content/uploads/2019/09/1568808134cplr.-reporton-criminal-statistics-in-ukraine.pdf

Shepitko, V.Yu. (2009). Forensic science. Kharkiv: Odyssey.

Shrub, M.P. (2018). Forensic technique. Minsk: Academy of the Ministry of Internal Affairs.

Slovo i Dilo. (2018). Crime in Ukraine. Statistics for the last year. Recovered from https://www.slovoidilo.ua/2018/02/16/infografika/ suspilstvo/zlochynnist-ukrayini-statystykamynulyj-rik

Zelensky, V. D., Meretukov, G. M., Gusev, A. V., \& Danilyan, S. A. (2013). Forensic technique of investigation of certain types and groups of crimes. Krasnodar: KubGAU. Recovered from https://kubsau.ru/upload/iblock/76d/76ded7826691 63af980be6aee9008916.pdf 